\title{
The use of reverse transcriptase-polymerase chain reaction (RT-PCR) to investigate specific gene expression in multidrug-resistant cells
}

\author{
Lorraine O'Driscoll, Carmel Daly, Mohamad Saleh* and Martin Clynes
}

National Cell and Tissue Culture Centre/Bioresearch Ireland, Dublin City University, Glasnevin, Dublin 9, Ireland

Key words: cancer, multidrug resistance, quantitative PCR, reverse transcriptase polymerase chain reaction (RT-PCR)

\begin{abstract}
Expression of specific genes at the level of mRNA can be studied using techniques such as Northern blot, slot/dot blot, RNase protection assay, in situ hybridisation and RT-PCR. In this article these methods of analysis are compared; RT-PCR offers higher levels of specificity and sensitivity than traditional methods of RNA analysis and as such has become the method of choice for the study of gene expression. The RTPCR technique is described in detail with sections dealing with RNA extraction, choice of primers (including the use of cDNA sequence data bases), PCR and RT-PCR protocols in addition to the limitations of the method. The study of one particular mRNA transcript (MDR1) using RT-PCR is discussed in detail. Recently described methods for quantitation of PCR products are discussed. Quantitative PCR would.appear to offer a method of studying gene expression in a more extensive way than has been possible to date.
\end{abstract}

\section{Introduction}

Control of transcription plays a critical role in the multistep process that regulates gene expression. Gene transcript levels within a cell change in response to a wide variety of signals that occur during cell development, differentiation and normal physiological function as well as in response to disease. Changes in transcription levels cause variations in the steady state levels of individual mRNAs. Thus, analysis of $m$ mNA levels of a gene is vital in a broad range of research areas.

Traditionally, levels of individual mRNAs have been analysed by procedures such as Northern blot
(Alwine et al., 1977; Thomas, 1980), RNA slot/dot blot (Kafatos et al., 1979), RNase protection assay (Reyes and Wallace, 1987) and in situ hybridisation (for details of method see Ausubel et al., 1991b). Application of the PCR technique provides another method of RNA analysis (for review see Wright and Wynford-Thomas, 1990; Larrick, 1992). This PCR based technique has been variously termed RNA-PCR (Kawasaki, 1991), RT-PCR (Rappolee et al., 1988a), RNA phenotyping (Rappolee et al., $1988 \mathrm{~b})$ or message amplification phenotyping (MAPPing) (Brenner et al., 1989). RT-PCR, because of its specificity, sensitivity, speed and accuracy, has become increasingly popular for the

"Visiting Postdoctoral Research Fellow from Scientific Studies \& Research Centre, P.O. Box 4470, Damascus, Syria. 
study of short-lived low copy number mRNA transcripts (Rappolee et al., 1988a; Murphy et al., 1990; Hoof et al., 1991; Horikoshi et al., 1992) and for the detection of unique mRNA transcripts from a background of normal cells (Chelly et al., 1988; Kawasaki et al., 1988; Lee et al., 1987). In addition, recent advances allowing quantitation of PCR products has meant that gene expression can be studied in a more extensive way than has been possible to date.

In the past, expression of eukaryotic mRNAs has been studied using the Northern blot technique (Alwine et al., 1977; Thomas, 1980). However, this method is insensitive, $(5-10 \mu \mathrm{g}$ quantities of purified polyadenylated RNA (poly (A) ${ }^{+}$RNA) is required to produce a signal) and cumbersome, necessitating the use of specific ${ }^{32}$ P-labelled probes for detection following electrophoresis and transfer of mRNA to filters. However, Northern blotting is semi-quantitative and does permit mRNA to be sized enabling, for example, the study of splicing patterns of mRNA. Another method used in the analysis of RNA is the slot/dot blot technique described by Kafatos et al. (1979). This method provides a semi-quantitative estimate of amounts of particular mRNAs present in a sample but is limited by its lack of sensitivity $(1-10 \mu \mathrm{g}$ of purified poly (A) RNA is necessary to produce a signal). In addition, the method is not dependable for detecting extremely rare sequences because of background problems.

RNase protection assays are more sensitive than Northern blotting, (100 $\mathrm{ng}$ to $1 \mu \mathrm{g}$ of poly $(\mathrm{A})^{+}$ RNA is required for each assay). The main disadvantages of this method is that it requires hybridisation for each mRNA, as well as the use of radioactive detection methods and sequencing gels.

A more sensitive technique for the analysis of $\mathrm{mRNA}$ is in situ hybridisation (see Ausubel et al. (1991b) for details of method) in which the temporal and spatial expression patterns of mRNA can be determined within complex cell populations and tissues. Using this method 10 to 100 molecules of mRNA can be detected in a single cell and 3-D information about transcript distribution and cellular localization can be obtained. However, in situ hybridisation can be technically difficult and does not lend itself well to the processing of a large number of samples. In addition, it is not possible to quantify mRNA amounts using this method.

These methods are not always sensitive enough to detect mRNA in samples limited by either low cell number or low copy number per cell. In addition, they permit only crude quantitation of mRNA.

\section{Reverse transcriptase-polymerase chain reaction (RT-PCR)}

Polymerase chain reaction (PCR) is an in vitro technique for the selective amplification of defined target DNA sequences. This technique was developed by Mullis and co-workers at the Cetus Corporation (Mullis and Faloona, 1987). In order to amplify a specific target sequence using PCR, some prior DNA sequence information about the target DNA locus is normally required. This information is needed to design two oligonucleotide primers which, when added to denatured DNA, will specifically bind to their complementary sequences on opposite strands, immediately flanking the desired target i.e., the region to be amplified. The primers anneal to opposite strands in such a way that the extension reaction directs the synthesis of DNA towards each other, both occurring in the $5^{\prime}$ to $3^{\prime}$ direction (see Fig. 1). In the presence of a suitable thermostable DNA polymerase enzyme and DNA precursors (the four deoxynucleotide triphosphates - dATP, dCTP, dGTP, dTTP), the synthesis of new strands of DNA, complementary to the individual primed DNA strands, is initiated.

DNA generally exists as a double stranded molecule. This must be denatured to single strands for the primers to recognise and bind to their complementary sequences. Denaturation occurs at $90-95^{\circ} \mathrm{C}$ and the temperature is then lowered to allow the primers to anneal. The optimum annealing temperature may range from $50^{\circ} \mathrm{C}$ to $75^{\circ} \mathrm{C}$; increasing the temperature improves the primer stringency. (The optimum temperature will depend on the $A+T$ and $G+C$ make-up of the primers, as will be discussed later). Extension of the annealed primers by the incorporation of free deoxy- 


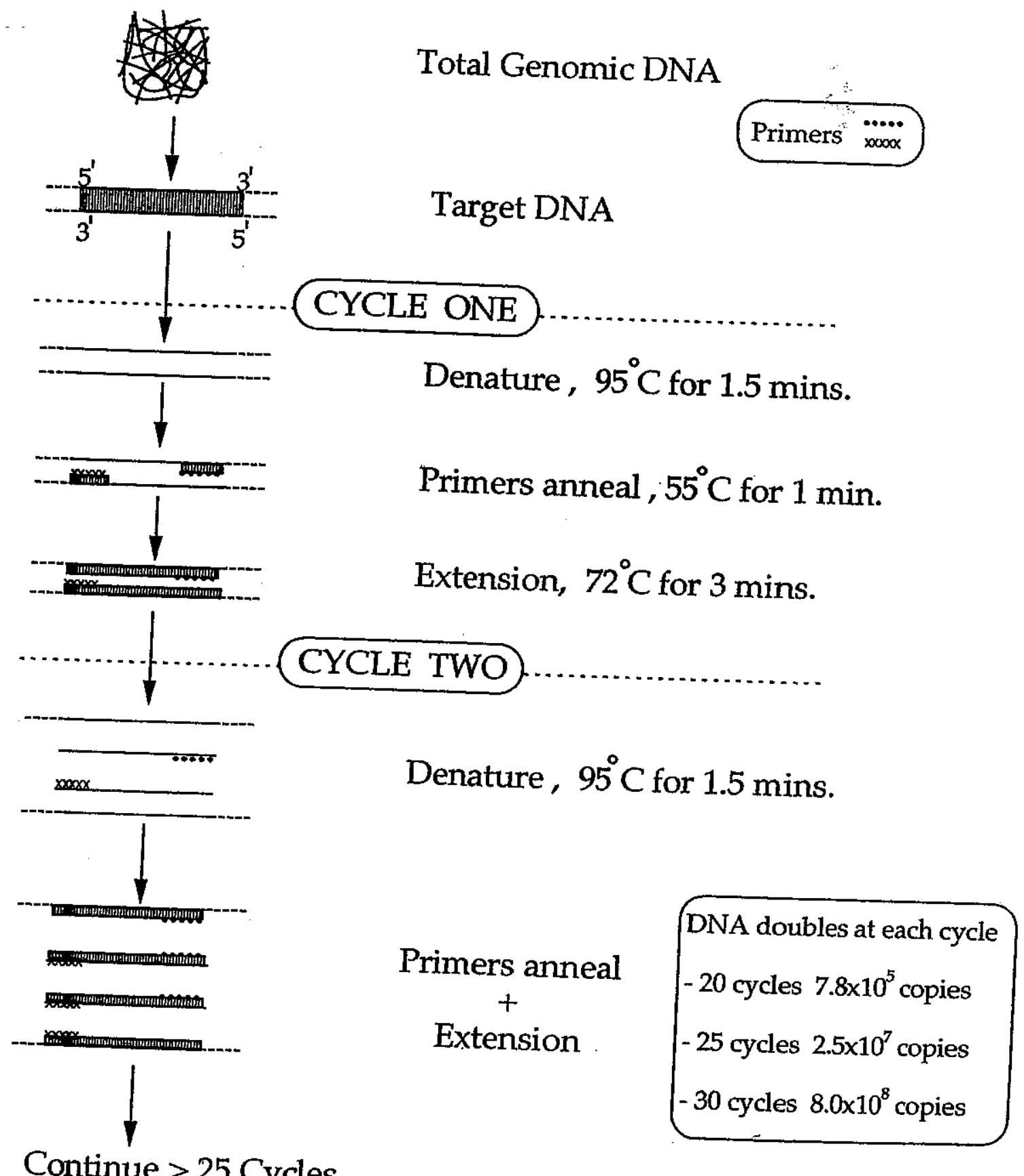

Fig. 2. Each of the primers is chosen so that it recognises one specific DNA sequence and does not bind to any other DNA sequence present in the DNA specimen. Each cycle of the polymerase chain reaction consists of a denaturation step where double-stranded DNA
is melted to single strands; an annealing extension step, where new strands of Ding step, where the primers bind to their specific recognition sites on the template; and an extension of the primers. The primers become formed, complementary to the primed single strands, by DNA polymerase enzyme of the amplified region. New strands of strands are synthesised exponentially. 
cesium chloride. The buoyant density of RNA in cesium chloride $(>1.8 \mathrm{~g} / \mathrm{ml})$ is much greater than that of other cellular components (Glisin et al., 1974). During centrifugation, RNA forms a pellet on the bottom of the tube, DNA is suspended at the interface and protein floats in the supernatant solution (see Protocol 1: Appendix 1).

mRNA must be selectively primed for it to act as a template on which double-stranded DNA, known as complementary DNA (cDNA), can be formed by a reverse transcriptase enzyme (See Protocol 2: Appendix 1). The cDNA area of interest, which is a direct copy of the mRNA, can then be amplified and studied as in a typical PCR (see Protocol 3: Appendix 1).

Oligo (dT) primers (for eukaryotic RNA), random hexanucleotide primers, or the $3^{\prime}$ antisense gene-specific primer used in the PCR reaction, may be used for this purpose. In choosing the primers for the RT reaction the following should be considered:

Oligo (dT) primers recognise and bind to the poly $(\mathrm{A})^{+}$tail $\left(3^{\prime}\right)$ of mRNA allowing it to be copied to cDNA, selectively (see Fig. 3). (A polyadenylated tail occurs on the 3' end of most, but not all, eukaryotic mRNAs (Ausubel et al., 1991c). The possibility of having long stretches of cDNA or even full-length cDNA made from mRNA have been found to be more likely using oligo (dT) primers.

Random primers, as their name suggests, bind randomly to the mRNA template and, again, the reverse transcriptase enzyme catalyses the formation of cDNA strands. These primers, rather than oligo (dT), are claimed to minimise the effects of mRNA secondary structure and the distance of the amplified sequences from the poly $(\mathrm{A})^{+}$tail. This is suggested to be of particular importance for the analysis of partially degraded samples of cellular RNA, such as are commonly isolated from tumours and other clinical specimens (Noonan and Roninson, 1991). Because of their random binding, a mixture of short and long cDNA stretches may result.

The $3^{\prime}$ gene-specific complementary primer binds selectively to the $3^{\prime}$ region flanking the mRNA locus of interest. Some advantages of using the downstream gene-specific primer include the fact that cDNA including the specific area of interest should result. It is also convenient as an aliquot of this primer will be used in both the RT and the PCR reactions.

Alternatively, the advantage of using oligo (dT) primers or hexanucleotide primers over genespecific primers for CDNA synthesis is that the products of a single RT reaction can be used for amplification of multiple mRNA sequences, either in the same PCR reaction, or separately. In this way, the cDNA of interest can be amplified simultaneously with an internal standard (see Protocol 2: Appendix 1).

\section{Applications of RT-PCR}

Adaptation of PCR to the detection of RNA has increased the sensitivity of detection of a particular mRNA species by several orders of magnitude (with the exception of in situ hybridisation). RTPCR is 1,000 to 10,000 times more sensitive than the traditional RNA blot techniques (Byrne et al., 1988; Wang et al., 1989; Rappolee et al., 1989; Mocharla et al., 1990; Singer-Sam et al., 1990) e.g., Mocharla et al. (1990) have reported that RTPCR amplified cDNA was obtained from as little as $5 \mathrm{pg}$ of human pancreatic or parotid total RNA, yet transcripts were not detected on Northern blots unless at least 15-30 ng of pancreatic total RNA was used. As a result of this sensitivity, RT-PCR can be used to analyse RNA of extremely low abundance (Chelly et al., 1988), mRNAs in small numbers of cells ( 1 to 1,000 cells (Kawasaki et al., 1988; Rappolee et al., 1989)) or in small amounts of RNA (as little as $6 \mathrm{pg}$ of total RNA (Rappolee et al., 1989; Wang et al., 1989; Mocharla et al., 1990; Kawasaki, 1991)). Expression of multiple mRNAs can be determined simultaneously from a single sample of RNA, a difficult task by traditional methods. Purification of poly (A) ${ }^{+}$mRNA is rarely necessary for RT-PCR analysis. RT-PCR should be of particular benefit in clinical studies, where biopsy samples may not provide enough material for accurate analysis by traditional immunological and biochemical methods.

The sensitivity of PCR can be one of the disad- 
vantages of the system. As a result of the exponential nature of PCR, even trace contamination of reagents, samples and apparatus, with cloned or PCR derived sequences, may lead to false positives.

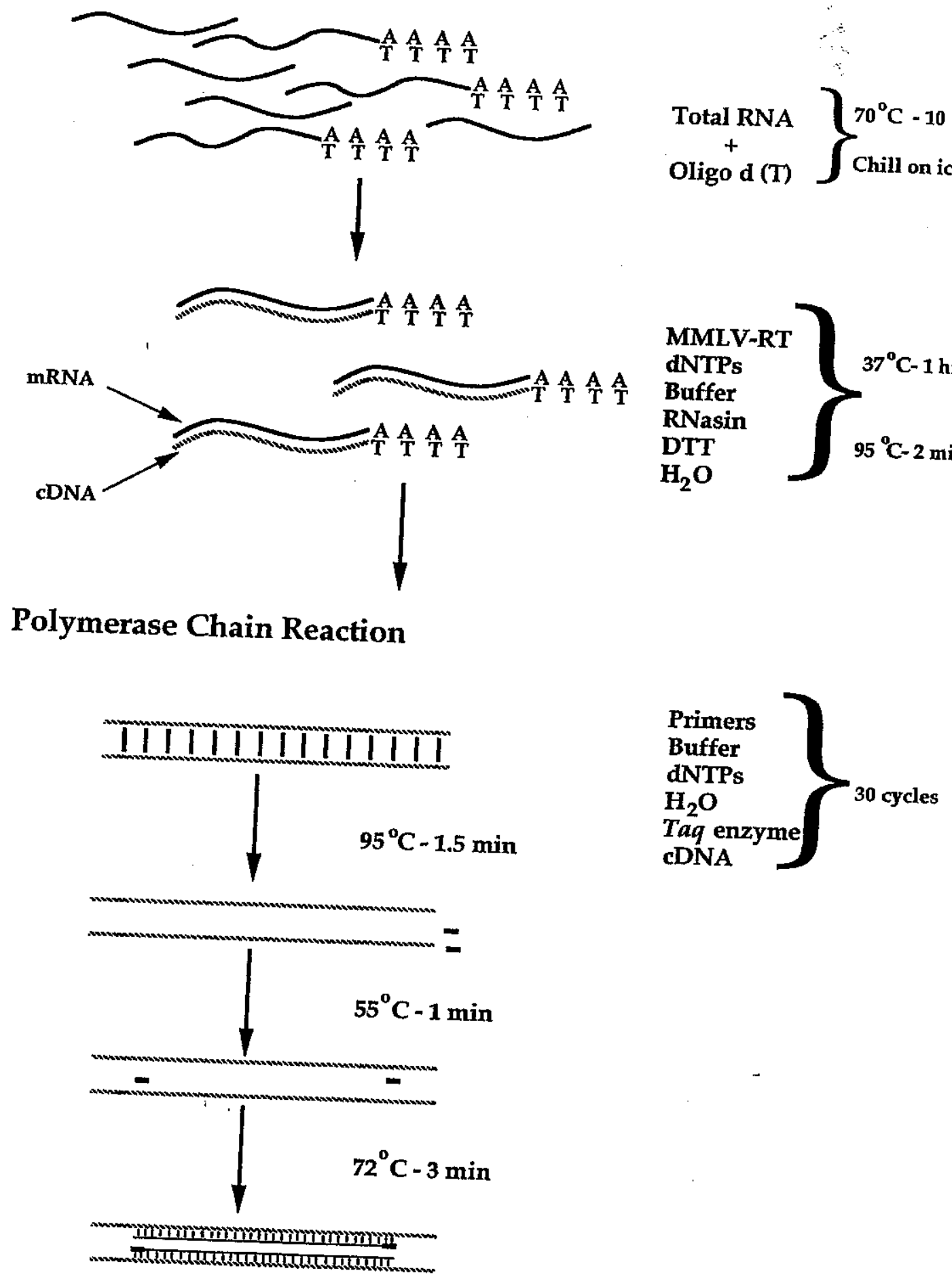

Fig. 3. Oligo (dT) may be used to prime the poly (A) tail of mRNA. cDNA is formed on this template by reverse transcription. Specific cDNA regions of interest can then be amplified by PCR for their analysis. 
Unlike the results obtained using Northern blotting, RT-PCR does not provide information on the size of the transcripts of interest. Although RT-PCR provides an ideal method to survey the expression of multiple genes simultaneously in diverse populations of cells, subpopulations of cells may provide unacceptable background signals. Expression of genes in cells should be treated with caution as it may not indicate physiological significance e.g., using RT-PCR Chelly et al. (1988) detect expression of several tissue specific genes in cells not expected to express these genes; this phenomenon has been termed "illegitimate" or "leaky" transcription. This leads to the question as to whether levels detected by PCR are clinically or physiologically relevant and whether in all cases functional protein expression results. For example, in the case of $M D R 1$ (the multidrug resistance gene) low level expression may be as a result of leaky transcription or possibly may represent subpopulations of $\mathbf{P}$ glycoprotein expressing cells within a tumour. A positive result may be obtained from an RNA preparation from a tumour which may only represent the expression of a gene in a subpopulation of tumour cells. These cells would have a growth advantage in the course of chemotherapy. Low level expression may be significant for some tumour types. Clinical correlative studies are necessary to establish whether low levels of $M D R I$ expression would be prognostically significant for different tumours; recent results by Holzmayer $e t$ al. (1992) suggest that such correlations may indeed be clinically relevant:

RT-PCR can be used for the detection of transcripts that display variable expression patterns in issues and during development (Chelly et al., 1988; Rappolee et al., 1988a; Chin et al., 1989) .g., the dystrophin gene, defective in patients with nuscular dystrophy is expressed at very low levels representing only $0.01-0.001 \%$ of total muscle nRNA) making it difficult to study by conventionI methods. RT-PCR was successfully used to study evels of dystrophin mRNA in clinical samples Chelly et al., 1988).

\section{RT-PCR in the study of multidrug-resistance}

The multidrig resistance gene $M D R I$ has also been studied by RT-PCR, as conventional methods were often unsuccessful at detectiog expression of this gene (Roninson et al., 1986; Gekeler et al., 1990; Fuqua et al., 1990; Murphy et al., 1990). The multidrug resistance phenotype is characterised by cross resistance to a large group of lipophilic cytotoxic compounds including plant alkaloids and antitumour antibiotics. Multidrug resistance is associated with decreased intracellular drug accumulation and correlated with the increased expression of MDR genes, which encode membrane glycoproteins (P-glycoproteins) of approximately $170 \mathrm{kDa}$ (Juliano and Ling, 1976; Roninson et al., 1986; Ueda et al., 1986; Roninson, 1987; Gottesman and Pastan, 1988). Expression of a single human gene, designated $M D R I$, is sufficient to confer the multidrug resistance phenotype to drug sensitive cells (Gros et al., 1986; Shen et al., 1986a; Ueda et al., 1987; Choi et al., 1988). Even very low levels of $M D R 1$ gene expression can confer a severalfold increase in the level of drug resistance which may be clinically significant (Shen et al., 1986a; Chin et al., 1989). MDRI expression has been analysed by conventional RNA slot/dot blotting techniques (Goldstein et al., 1989; Fojo et al., 1987; Bourhis et al., 1989) and Northern blots (Shen et al., 1986b; Roninson et al., 1986; Fojo et al., 1987; Kramer et al., 1993). However, in cells with a several fold increase in cellular drug resistance MDRI expression levels are close to the limits of sensitivity of conventional methods even when large amounts of RNA are used for the assay (Shen et al., 1986b; Fojo et al., 1987; Noonan et al., 1990). RNA blotting techniques may not be specific or sensitive enough to detect low levels of $M D R I$ gene expression which may be sufficient for clinically relevant multídrug resistance (Shen $e t$ al., 1986b; Noonan et al., 1990; Noonan and Roninson 1991; Holzmayer et al., 1992).

There are a number of additional problems in the study of gene expression in multidrug resistant cells under clinical conditions. The amount of available tissue is often limited; analysis of RNA from these samples is often problematic because 
RNA may have suffered significant degradation. Detection of $M D R I$ is often complicated by the existence of a homologous gene, $M D R 3$, which is apparently not associated with resistance to chemotherapeutic drugs; $M D R 3$ gene products often show cross reactivity with some $M D R l$ reactive antibodies and nucleic acid probes. When using $M D R I$ and MDR3 DNA probes high stringency. hybridisation conditions are required to avoid cross hybridisation of $M D R 3$ probes with $M D R I$ RNA. This limits the sensitivity of the assay and as a result cells with a low degree of resistance may escape notice. MDR expression in tumours is often heterogeneous with only a subpopulation of tumour cells expressing the gene (Weinstein et al., 1990). Even if some cells in the tumour express the gene at a relatively high level, heterogeneity may lead to a very low signal when total RNA extracted from the tumour is analysed. Subpopulations of P-glycoprotein expressing cells within the tumour may have a growth advantage in the course of chemotherapy (Noonan et al., 1990). The advancement of PCR based technology has provided a sensitive, specific and quantitative protocol for measuring the levels of $M D R I \mathrm{mRNA}$ in clinical samples which overcomes nany of these drawbacks. PCR methods require nuch less tissue than traditional methods and so re applicable to the detection of $M D R l$ in clinical amples, even from a heterogeneous population of ells. In addition, by careful choice of sequencepecific primers, it is possible to amplify selectiveeven such highly related sequences as MDRI nd $M D R 3$.

Noonan et al. (1990) used a quantitative PCR ssay to study $M D R l$ mRNA expression in a large umber of both normal and tumour tissues. They port $M D R I$ expression which was rarely observed ing standard (slot/blot) assays. Similarly, Chin et (1989) used PCR to detect the presence of $D R I$ and $M D R 3$ mRNA in a number of multidrug sistant cell lines which had not been detected by orthern hybridisation using $M D R I$ and MDR3 nomic clones (Roninson et al., 1986). Both of ese studies, while agreeing with the results tained using standard blot techniques on tissueecific distribution of MDRI RNA (Fojo et al., 87), report that the PCR assay also detects
MDRI expression in some tissue which had not been evident using Northern or slot blots. Fuqua et al. (1990), Gekeler et al. (1990), Murphy et al. (1990), Hoof et al. (1991) and Hegewisch-Becker et al. (1993) report the detection of MDRl mRNA (using RT-PCR) in cells and tissues in which other workers (Fojo et al., 1987), using conventional RNA blot techniques, have either not detected expression or found expression to be extremely low. PCR would appear to provide a clinical tool comparable to Northern analysis in accuracy but greatly exceeding its sensitivity.

In conclusion, RT-PCR is superior in ease, speed, sensitivity and resolution to mRNA analysis by in situ hybridisation, RNA (Northern) blot and RNase protection assays and as such provides the only method of accurate mRNA analysis if quantities of RNA are limited.

\section{Precautions/artifacts/limitations}

As with all PCR studies, general precautions must be taken and good laboratory procedures exercised. These include prealiquoting all solutions in small amounts and discarding the remains after each use; physically separating the reaction preparation from the amplified products; the use of separate pipettes etc. for setting-up the reaction and analysing the product; and optimising the conditions for each set of templates and primers. Primers must be chosen carefully, avoiding the possibility of primer-dimer formation etc. (see "Criteria to follow when choosing primers"). This is of particular importance where more than one primer pair is included in a reaction which would be the case if primers were also included to amplify an internal control, such as $\beta$-actin. Extra care must be taken in this case to ensure that no two of the four primers included will form "primer-dimers". More obvious precautions include autoclaving all necessary solutions, eppendorfs, pipette tips etc. and wearing gloves, as previously discussed. Reaction components should be added on ice and the accuracy of the pipettes monitored regularly. This last point, although somewhat obvious, is extremely important for these procedures as the volumes involved are quite small. 
Due to the sensitivity of this technique a very small inaccuracy in setting up the reaction components could result in a very large inaccuracy in the final product.

Good experimental design is very important. This involves including negative controls to detect contamination and positive controls to ensure the reaction is conducted successfully (discussed later). All reactions should be set up at least in duplicate. To standardise the procedure, it is generally considered better to prepare a master-mix of all the ingredients including the enzyme and aliquoting (on ice) just prior to the template addition. The minimum number of PCR cycles required should be carried out in order to minimize the chances of a rare contaminating template being amplified.

Extra precaution (as previously discussed) must be taken when studying RNA e.g., baking glassware, DEPC-treating solutions. Furthermore, it must be possible to discriminate between the RNA product and that of contaminating DNA. Although great care is taken when extracting RNA after sedimenting through the cesium chloride cushion, the possibility of DNA contamination (from the cesium chloride: guanidinium thiocyanate interface) should not be ruled out. To overcome this, primers from different exons should be used whenever possible. Different product sizes will then result if mRNA or DNA is used as the template.

To confirm amplification of the expected molecules, cleavage with a restriction endonuclease enzyme whose site of recognition in the amplified fragment is known, should be included. Alternatively, hybridisation with an internal oligonucleotide can be done. This is claimed to increase the sensi-. tivity by allowing detection of amplification products not visualised by ethidium bromide staining (Ausubel et al., 1991c).

\section{Quantitative PCR}

Although RT-PCR has many advantages over RNA blot methods it had been difficult to obtain quantitative data on the expression of individual genes using PCR based methods. RT-PCR requires two enzymatic steps, synthesis of the cDNA template and PCR amplification. Both steps must be considered in any attempt to quantitate mRNA. Efficiency of cDNA synthesis can be monitored by the incorporation of ${ }^{32} \mathrm{P}$ labelled dNTPs into TCA precipitable material. As PCR amplification is an exponential process, small variations in amplification efficiency or in any of the variables that control the reaction (e.g., concentration of polymerase, dNTPs, magnesium, DNA or primers) can drastically affect the yield of products and in so doing obscure differences in the initial amounts of target sequences (Gilliland et al., 1990a; Bloch, 1991). In addition, the efficiency of PCR decreases at the later stages of amplification due to depletion of reaction components, diminished enzymatic activity and accumulation of products (see "RT-PCR. Methods and Applications", (Clontech Labs) 1991). Therefore, any attempt to quantitate mRNA levels by PCR must be limited to the analysis of products generated only during the exponential phase of the amplification. Under these conditions RT-PCR can yield reasonably precise information about relative changes in mRNA levels.

PCR product concentration is proportional to the starting target DNA as long as product accumulation remains exponential (Chelly et al., 1988; Singer-Sam et al., 1990). The point at which exponential accumulation plateaus can be roughly estimated by noting the point at which continued cycles do not produce significantly increased product yield. RT-PCR can detect changes in mRNA levels of greater than two-fold without the use of any internal standard. Singer-Sam et al. (1990) used RT-PCR quantitatively to measure accumulation of RNA transcripts in total mouse RNAs derived from male germ cells at various spermatogenic stages. By limiting the amount of input template and the number of cycles of PCR, they obtained a signal which was linearly related to specific RNA levels over at least a thousand fold range, with reproducibility adequate for any study where changes in RNA levels were greater than two-fold.

For more accurate quantitation of mRNA levels corrections for reaction-to-reaction variation in amplification efficiency are necessary. Amplification of replicate samples of plasmid results in product yield which can vary by as much as six- 
fold (Gilliland et al., 1990b). RT-PCR, although renowned for its high sensitivity, specificity, ease and speed, can also be a technique of variable efficiency between preparations and between RNA species. This variability may be due to a number of reasons including the fact that the procedure consists of a number of individual techniques - extracting RNA; quantifying the RNA spectrophotometrically; forming cDNA on the mRNA template; and amplifying the region of interest. Taking into account e.g., the extraction efficiency, the number of very small volume additions etc., it is understandable that some amount of variability may occur even when extreme care is exercised.

For this reason, it is very important to include an internal control in each RT-PCR. Such a control may be the product of an ubiquitously expressed gene (e.g., a "house-keeping" gene product). As this is extracted at the same time, by the same procedure, using the same solutions, from the same population of cells (subjected to the same contaminants/inhibitors); quantified also as part of the total RNA and included in the same RT and PCR reactions as the mRNA to be analysed, the products of the two should be directly comparable.

The uses of such a control are two-fold. If no signal from the sequence of interest is obtained in a given sample, the internal control will verify whether this is a true (if internal control is present) or false (if both are absent) negative. It is not uncommon for amplifications to fail, especially since some experimental samples contain contaminants that interfere with DNA replication (Ausubel et al, 1991c) or inhibitors of Taq DNA polymerase e.g., porphyrin compounds derived from heme, that may be a problem if contaminating the DNA extracted from blood cells (Higuchi, 1989). Secondly, the intemal control allows for quantitation since it normalises for several factors including variation in the amount of sample RNA; efficiency of the RT reaction; efficiency of amplification and the amount of product loaded on the gel.

The internal control PCR product should differ enough in size to be resolved from the product of interest, but close enough so as to minimise the probability of differences in amplification efficiency. It should also be distinguishable in size from artifactual "primer-dimers" that may be produced.

When such an internal control is used for this purpose, either $\beta$-actin or $\beta_{2}$-microglobulin are generally chosen. Esterase $D$ has also been favoured by some researchers (Cole et al., 1991).

\section{B-Actin}

Actin is the most abundant structural protein in eukaryotic cells (Nakajima-Iijima et al., 1985; Pollack, 1980; Firtel, 1981; Fulton, 1981). Its amino acid sequence has been highly conserved during evolution (ranging from 1.1 to $6.2 \%$ difference in amino acids). At least six isoforms exist in vertebrates. Four actin types are involved in muscle contraction including skeletal, cardiac, aortic type smooth muscle and stomach-type smooth muscle forms. The muscle-type actins are tissue-specific.

The cytoplasmic actins (nonmuscle) $-\beta$ and $\gamma-$ coexist in many cell types and are involved in a variety of functions. Multiple gene copies related to the cytoplasmic actins have been found to exist, most of which seem to be pseudogenes (Engel et al., 1981; Moos and Gallwitz, 1982; Moos and Gallwitz, 1983; Ponte et al., 1983). Abnormal expression of cytoplasmic actin has been found to be associated with neoplastic transformation of human fibroblasts (Leavitt et al., 1982; NakajimaIijima et al., 1985).

From the primer sequences published for amplification of $\beta$-actin it seems to be very difficult to choose sequences which are specific for $\beta$-actin and do not recognise $\beta$-actin pseudogene, mutated $\beta$ actin, $\alpha$-actin or $\gamma$-actin. It is important to be aware of this, particularly if a range of tissue types are to be studied, as the levels of the various actin forms may differ greatly from tissue to tissue and so may not act as a good standard. It may be important to choose different isoforms of actin as internal standards, depending on the tissue type being studied. $\beta$-actin is generally favoured as a standard by many researchers including Horikoshi et al. (1992), Avraham et al. (1992) and Lönn et al. (1992).

\section{$\beta_{2}$-microglobulin}

$\beta_{2}$-microglobulin has also been used as an internal 
control (Noonan et al., 1990). $\beta_{2}$-microglobulin is a small (12 kDa) polypeptide found in serum and associated with the major histocompatibility complex class 1 heavy chain on the surface of nearly all cells (Guissow et al., 1987). It has been claimed by others as a gene that is ubiquitously expressed and its expression correlates with the cell surface area in most cell types (Noonan et al., 1990). Noonan et al., (1990) suggested that as the amount of $\beta_{2}$-microglobulin is not constant in different cell types, but is proportional to the cell surface area, it may not be the best control for genes encoding for intracellular proteins.

In tumour types, including small cell lung cancer, the amount of $\beta_{2}$-microglobulin and another HLA-related gene may be decreased or eliminated (Doyle et al., 1985). Horikoshi et al. (1992) studied the ratios of $\beta_{2}$-microglobulin: $\beta$-actin and found a considerable variation among the tissues tested. This suggested that either one or both are not expressed at similar levels among different tissues. $\beta$-actin was found to be more constantly expressed and so was favoured as the internal standard.

\section{Esterase D}

Esterase $\mathrm{D}$ has also been chosen as an internal control by Cole et al., (1991) who claimed it to be less dependent on cell cycle than other genes e.g., $\beta$ and $\gamma$ actins. Because of the nature of their study they favoured esterase $D$ over $\beta_{2}$-microglobulin as they believed $\beta_{2}$-microglobulin to be often undetected in small cell lung cancer. However, the polymorphic enzyme esterase D (13q14) has been used as a marker for loss of heterozygosity in linkage analysis studies of the retinoblastoma gene (RB1). Mutations of the RB1 gene have been found in many tumour types and in particular, in small cell lung cancer. In $77 \%$ of small cell lung cancers studied, absence or trace levels of RB1 mRNA have been reported (Macdonald and Ford, 1991). It is possible therefore that esterase $\mathbf{D}$ may also be affected in this way. This would make it an unreliable control if its presence in all tumour types studied was uncertain.

It therefore would seem that no one endogenous sequence will be suitable as an internal control for all studies. As discussed in "Criteria to follow when choosing Primers", good experimental design will also involve choosing the best possible internal control - whether this be $\beta$-actin, $\beta_{2}$-microglobulin, esterase $\mathbf{D}$ or some other endogenous sequence.

For more reliable and precise quantitation of PCR amplification of specific mRNA species, a process termed competitive PCR has been developed. This method involves the co-amplification of a competitive template that uses the same primers as those of the target CDNA but can be distinguished from the target cDNA after amplification. Gilliland et al. (1990b) have compared the coamplification of target cDNA to cloned genomic sequences. Aliquots of the PCR mixture containing cDNA copies of the RNA to be assayed are added to serial dilutions of a competitive DNA fragment differing from the cDNA of interest by the presence a small intron i.e., primers are chosen in separate exons and flank the intron. Amplification of the competitor yields a PCR product larger than the target mRNA region. The dilution at which the control and cDNA products are equivalent indicates that the starting concentration of CDNA prior to PCR is equal to the known starting concentration of the competing control plasmid. Using this method, the reference templates share with the target sequence the same primer sites and near totality of the amplified sequence so that the two templates compete for the same primer set and subsequently amplify at the same rate (competitive PCR), as any variable affecting amplification has the same effect on both. However, there may be differences in the amplification efficiency of genomic and complementary DNAs i.e., differences in the size of the target sequences may affect amplification. Therefore, the presence of an intron in genomic sequence may have an affect on quantitation.

In an attempt to minimize sequence variation a number of studies have been carried out which use a competitive template that contains a single base pair change (from the target) which results in the creation of a restriction site (Becker-Andre and Hahlbrock, 1989; Gilliland et al., 1990b). This method has been termed PCR aided titration assay (PATTY). Competitive templates containing changes in a single base pair can easily be synthesized 
by using PCR for site directed mutagenesis (Higuchi et al., 1988). After PCR amplification, the competitor can be identified by restriction digestion. In their studies Gilliland et al. (1990b) compared the efficiency of using competitive templates containing small introns and those containing a single base change to create a restriction site. They report that the amplification efficiencies for each were identical.

However, there are a number of potential problems when using competitors containing small introns or altered restriction sites. They do not provide a control for the efficiency of the reverse transcription step of RT-PCR. In addition, quantitation may be complicated by the possible formation of heterodimers between native and mutated amplified products during later amplification cycles (Becker-Andre and Hahlbrock, 1989; Gilliland $e t$ al., 1990b). Since heterodimers are not recognised as substrates for restriction enzymes, quantitation can be artificially skewed towards uncleaved products. In addition, a competitive template must be constructed for each gene to be analysed which is often tedious and involves mutagenesis and cloning.

In order to provide a control for the reverse transcriptase step of the process, cRNA templates have been utilised (Becker-Andre and Hahlbrock, 1989; Wang et al., 1989; Wang and Mark, 1990; Gaudette and Crain, 1991). RNA competitors are derived from the in vitro transcription of the mutated DNA fragment containing the recognition sequence of T7 RNA polymerase at one extremity (Wang et al., 1989). By reverse transcription and amplification of the target mRNA and cRNA strand. in the same tube, variable effects due to differences in sample preparation, conditions of reverse transcription or the PCR amplification are internally controlled and will affect the yield of PCR product equally for the target mRNA and the standard cRNA.

In an attempt to overcome both the problem of heterodimer formation and the necessity to create different competitors for each gene Wang et al. (1989) have used a synthetic RNA as an internal standard. This artificial gene consists of twelve target gene upstream primers connected in sequence followed by the complementary sequences of their downstream primers in the same order. The intervening DNA bears no sequence relation to the target RNA. It has been shown that amplification efficiency is primarily determined by the primer sequences unless there are significant differences in denaturing or polymerase extension characteristics due to high $G / C$ content or secondary structure (Wang et al., 1989; Siebert and Larrick, 1992). Differences in sequence content between target and competitor RNAs is believed to have a minimal effect on amplification efficiency. Using this cRNA in competitive PCR, differences in the reverse transcriptase step can be analysed and, in addition, the same standard can be used to quantitate a number of different genes. The fact that target and competitor sequences are different eliminates the problem posed by heterodimer formation.

Using competitive RT-PCR it is possible to obtain quantitative information on mRNA distribution comparable to RNA blot analysis. mRNA species can be accurately quantitated from $1 \mathrm{ng}$ of total RNA or as few as 10 cells (Becker-Andre and Hahlbrock, 1989; Gilliland et al., 1990a; Bej et al., 1991; Gaudette and Crain, 1991). Wang et al. (1989) report that they have used quantitative PCR to reliably quantitate the amount of a specific mRNA in a sample of $<0.1 \mathrm{ng}$ of total RNA. They state that they can measure $10^{4}$ molecules which is 1,000 times more sensitive than the dot blot assay.

Due to its sensitivity, speed and accuracy quantitative PCR can be used for the study of gene expression in a more extensive way than has been possible to date, allowing analysis of changes in the levels of expression of specific RNA molecules. This is of benefit in the diagnosis and analysis of cancer, metabolic disorders and autoimmune diseases. $\mathbf{A}$ number of studies have been carried out using competitive PCR to analyse the expression of $M D R 1$ in normal tissues, tumour derived cell lines and clinical specimens of untreated tumours (Noonan and Roninson, 1988; Murphy et al., 1990; Noonan et al., 1990). These studies have resulted in the detection and quantitation of $M D R l$ gene expression which was rarely possible by standard assays. 


\section{Criteria to follow when choosing primers}

The following is a list of guidelines for the design of oligonucleotide primers. Due to the uniqueness of each situation's requirements, it may not be possible, or indeed necessary, to conform to all of the guidelines listed.

\section{Complementarity to template}

The fundamental requirement for a primer is that it should hybridise efficiently to the sequence of interest with negligible hybridisation to other sequences present in the sample. (If sufficient amounts of template are available, this can be tested by performing oligonucleotide hybridisation, Ausubel et al., 1991c).

\section{Target length}

The distance between the primers for which optimum amplification can be achieved is generally considered to between 180 and $500 \mathrm{bp}$. However, much longer targets may be amplified efficiently. Amplifications of sequences up to $10 \mathrm{kbp}$ in length are sometimes attempted successfully (Ausubel $e t$ al., 1991c) but long sequences may be difficult to amplify consistently. A considerable drop-off in synthesis efficiency has been found with distances $>3 \mathrm{kbp}$ (Jeffreys et al., 1988).

The sequence length amplified will obviously be determined by the requirements of the study. For the purpose of RFLP analysis, for example, it is desirable to have a reasonably short distance between primers with the restriction site approximately central (Ivinson and Taylor, 1991). Alternatively, small distances between primers lessens the ability to obtain much sequence information or to reamplify with nested internal oligonucleotides, should that be necessary (Ausubel et al., 1991c). The fidelity of the DNA polymerase enzyme used in the PCR reaction (i.e., the number of errors produced per nucleotide synthesized) should be taken into consideration when deciding on the target length. Taq DNA polymerase does not have a $3^{\prime}-5^{\prime}$ proofreading exonuclease activity to remove nucleotides that have been misinserted during polymerisation. The longer the sequence being amplified with Taq, the more mismatches will be present. Other DNA polymerase enzymes e.g., the T4 and native T7 DNA polymerases are proofreading-proficient and are very accurate with regards to base substitution and one base frameshift mutations. The Klenow fragment of $E$. coli. DNA polymerase I also contains $3^{\prime} \rightarrow 5^{\prime}$ exonuclease, but the proofreading activity is much weaker than that of T4 or native T7 DNA polymerase. However, the T4, native T7 and Klenow DNA polymerase are heat labile and operate optimally at $37^{\circ} \mathrm{C}$. Using such low temperatures increases the probability of nonspecific annealing of primers to other regions of the DNA and also the likelihood of secondary structure formation being a problem (Eckert and Kunkel, 1991).

For many applications, primers are designed to be exactly complementary to the regions flanking the target sequence. For other purposes, such as engineering of mutations, introducing new restriction sites or for efforts to detect or clone gene homologs when sequence information is lacking, base-pair mismatches will be intentionally or unavoidably created. As far as is possible, it is advisable to include these mismatches as a "tag" near the 5 ' end of the primer. This should have no effect on the amplification reaction. When incorporating a modification at an internal point in the primer, the fewer the number of modifications, the better i.e., 1-2 changes (Clarkson et al., 1991).

Overall, it is best to include any changes as far from the $3^{\prime}$ end of the primer as possible; at least 10-12 bases from the $3^{\prime}$ end of the primer (Clarkson et al., 1991). A mismatch in the 3' area could prevent extension. When only the protein sequence is available, mixed oligonucleotide primers, known as degenerate oligonucleotide primers, derived from an amino acid sequence may be used. This has had some, but in many cases, limited success (Compton, 1990). Again, the less degenerate the oligonucleotides, especially at the $3^{\prime}$ end, the better (Ausubel et al., 1991c). This can be achieved by choosing primers with conserved amino acids which have nondegenerate codons (e.g., Trp and Met) at the $3^{\prime}$ end. 


\section{Primer length}

The length of a primer contributes to its specificity. It is generally considered ideal to choose oligonucleotide primers between 18 and 30 bases in length; however, shorter and longer primers will work. Low complexity DNA e.g., plasmids or previously amplified DNA, can be successfully amplified with shorter primers. This is because the template itself is more "selective" than, for example, a total genomic DNA sample, with a large proportion of the sample consisting of the template of interest. For this reason, the chances of the primers annealing to and amplifying an unwanted template are minimised. Longer primers are often favoured to improve specificity. (However, it is unlikely that primers longer than 30 bases will help improve specificity significantly - Ausubel et al., 1991c). The length of a pair of primers should be similar, if not equal.

\section{Annealing temperature}

The annealing temperature of primers is determined by their length and base composition. Increasing this temperature enhances discrimination against incorrectly annealing primers and so reduces the extension of incorrect nucleotides at the $3^{\prime}$ end of the primer. It is considered advisable to choose primers whose melting temperature $(T m)$ i.e., the temperature at which half of the duplex is dissociated (Kimmel, 1987) are between $55^{\circ} \mathrm{C}$ and $75^{\circ} \mathrm{C}$ (Rappolee, 1990). The appropriate PCR annealing temperature may be equal to the melting temperature or $5^{\circ} \mathrm{C}$ below this temperature (Innis and Gelfand, 1990). The $T m$ for a given primer can be estimated using the following equation (Bej et al., 1991):

$T m=2^{\circ}$ (no. of $\mathrm{A}+\mathrm{T}$ residues $)+4^{\circ}$ (no. of $\mathrm{G}+\mathrm{C}$ residues)

\section{Base composition}

Whenever possible, primers should have a balanced G/C and A/T concentration. Primers with a random base distribution should be selected, avoiding stretches of polypurines or polypyrimidines. This, again, is to try to prevent nonspecific binding e.g., stretches of T's binding to poly $(A)^{+}$tails, and to inhibit secondary structure formation. A pair of primers should not be complementary to each other, especially at their $3^{\prime}$ end, to avoid the formation of "primer-dimers". (This results when the $3^{\prime}$ end of one primer anneals to the $3^{\prime}$ end of the other primer, forming an amplified product which will compete with the target of interest in the PCR; as well as being, basically, a waste of primers). Individual primers should not be selfcomplementary e.g., they should not possess palidromes. This is to avoid secondary structure formation.

\section{Location of primers on template}

- Primers should frame a sequence as far $3^{\prime}$ as possible so that cDNA produced by oligo (dT) priming need not be full-length to act as template in the PCR (Rappolee, 1990). However, when the genomic structure is not known, primers separated by 300 to 400 bases in the $5^{\prime}$ portion of the coding region should be chosen. This is because exons larger than 300 bases in this area are fairly rare in vertebrates. Avoiding areas which may possibly be degraded in mRNA should be a main consideration (Hawkins, 1988).

- Where possible, areas that are likely to present problems of secondary structure (as detected by a number of computer programs e.g., OLIGO (Rychlik and Rhoads, 1989) should be avoided.

- Primers should flank a sequence that crosses an intron so that DNA contamination can be diagnosed.

- Primers should span introns so that primer-DNA annealing will not occur.

- Primers should frame a sequence with a diagnostic restriction site for validation purposes.

- Primers should frame a sequence that covers a cDNA insert possessed by the laboratory, whenever possible, so that the cDNA can be used as a positive control (discussed above) and/or for validation by Southern blot analysis.

- Primers can be chosen specifically for a single member of a gene family by choosing an area 
that is unique for that member. Alternatively, a region conserved by a particular gene family may be selected for a more general study of the family. Primers can be chosen for regions of interspecies homology so that the same set of primers can be used for each species or so that primers are sufficiently complementary to hybridise with cDNA from a species with unknown sequences of the gene of interest. Alternatively, primers unique to a particular species may be chosen.

\section{Sequence banks}

Primers should be selected in such a way as to minimise the possibility of their binding to other templates present in the specimen. If one primer binds to an extra template this will result in a waste of primers, etc. However, if both primers recognise and bind to the extra template, not only will reaction components be wasted, but an extra region may be amplified unintentionally.

To prevent this happening, the primer sequences can be sent to a DNA data-base e.g., EMBL data bank. (See Appendix 2). At EMBL, the submitted sequence is compared to all the stored sequences, and the first 50 sequences for which it shows strongest homology are listed. For the first 30 of hese, the sequences are aligned, their percentage comology calculated and the position on the temlate shown.

It must be remembered, however, that this is not comprehensive list, but only the first 50 sequencs of common homology. Other templates not listed ould possibly share enough sequence homology to. dlow the primers anneal.

\section{xamples of primers chosen in our laboratory}

number of primers have been chosen in this boratory to enable mRNA of multidrug resistance MDR) related factors to be detected. All primers o not fit all suggested criteria; primers chosen epresent our best attempts to compromise between e conflicting requirements of the different criteria. ee Table 1 for details.

\section{$M D R l$}

The primers published by Noonan et al. (1990) are both $100 \%$ homologous to the $M D R l$ mRNA template, resulting in a region of 157 bp being amplified. A diagnostic restriction enzyme recognition site for this $M D R I$ region was chosen in this laboratory. Digestion with Mae 1 results in products of $84 \mathrm{bp}$ and $73 \mathrm{bp}$. The primers are equal in length and the annealing temperature for both fit into the recommended range of $55^{\circ} \mathrm{C}$ to $75^{\circ} \mathrm{C}$. Neither primer contains palindromes or stretches of polypurines or polypyrimidines. The region amplified by these primers is from position 2,596 to 2,752 bp and the poly $(\mathrm{A})^{+}$tail commences at position $4,223 \mathrm{bp}$. The primers flank a sequence that crosses an intron so that DNA contamination can be diagnosed. If the relevant area of DNA was amplified, a band of $1,257 \mathrm{bp}$ would result in comparison to a band of $157 \mathrm{bp}$ from cDNA. The primers were selected to amplify only $M D R 1$ (avoiding $M D R 3$ ). Both primers share homology with a number of other human nucleotide sequences. However, their only common homologies are MDRI mRNA (for which they were selected) and $M D R I$ gene. By virtue of the fact that the selected region has an intron present in the DNA, if contaminating DNA is amplified, it should be possible to identify it by its longer size in comparison to the amplified region of cDNA.

\section{Topoisomerase II, topoisomerase II $\alpha$ and topoi- somerase $I I \beta$}

Two isozymes of Topo II have been identified in mammalian cells - Topo II $(170 \mathrm{kDa})$ and Topo II $\beta$ (180 kDa). These enzymes differ not only in size but in other biochemical respects, such as the sequence specificity of binding to DNA (Drake $e t$ $a l ., 1989$; Jenkins $e t-a l$, 1992). Primers were chosen which allow amplification of Topo II in general by selecting a region that is common to both isozymes. Specific primers were also chosen for Topo $\Pi \alpha$ and Topo I $\beta$ so that their levels can be studied independently. This allows the levels of Topo I $\alpha$ and Topo II $\beta$ to be analysed individually, the overall levels of Topo II evaluated, and the results compared. 
Table 1. Primers to amplify cDNA formed by reverse transcription on mRNA templates of MDR related factors

\begin{tabular}{|c|c|c|c|c|c|c|c|}
\hline $\begin{array}{l}\text { Primer } \\
\text { length } \\
\text { (bases) }\end{array}$ & $\begin{array}{l}A+T: \\
G+C\end{array}$ & $T m$ & $\begin{array}{l}\text { Amplified } \\
\text { RNA } \\
\text { sequence } \\
\text { length } \\
\text { (bases) }\end{array}$ & $\begin{array}{l}\text { Diag- } \\
\text { nostic } \\
\text { R.E. }\end{array}$ & $\begin{array}{l}\text { Restriction } \\
\text { product } \\
\text { length } \\
\text { (bases) }\end{array}$ & $\begin{array}{l}\text { Corresponding } \\
\text { DNA length } \\
\text { (bases) }\end{array}$ & $\begin{array}{l}\text { Location on } \\
\text { template } \\
\end{array}$ \\
\hline
\end{tabular}

\begin{tabular}{|c|c|c|c|c|c|c|c|c|c|}
\hline MDR1 & $\begin{array}{l}(\mathrm{a})^{*} \\
(\mathrm{~b})^{*}\end{array}$ & $\begin{array}{l}20 \\
20\end{array}$ & $\begin{array}{l}10: 10 \\
11: 9\end{array}$ & $\begin{array}{l}60 \\
56\end{array}$ & 157 & Mae 1 & $84+73$ & $\begin{array}{l}1,257 \\
\text { (Chen et al., 1990) }\end{array}$ & $\begin{array}{l}2596-2615 \\
2733-2752 \\
\text { (Chen et al. }\end{array}$ \\
\hline
\end{tabular}

$\begin{array}{llllll}\text { MDR } 3 & \text { (a) } & 24 & 16: 8 & 64 & 321\end{array}$

(b) $24 \quad 15: 9 \quad 66$

MRP
(a) 21
$\begin{array}{lll}13: 8 & 58 & 203\end{array}$

(b) $21 \quad 11: 10 \quad 62$

Topo I
(a) 30
17:13 86

(b) 27

16:11 82

Topo II
(a) 18
10:8 52
(b) 26
$16: 10 \quad 72$

Topo II $\alpha$
(a) 21
$\begin{array}{ll}11: 10 \quad 62 \\ 12: 14 & 80\end{array}$
(b) 26
12:14 80

Topo II (a) 30

(a) 30
(b) 28

19:11 82

18:10 76

$\begin{array}{llll}\text { (a) } & 18 & 8: 10 & 56 \\ \text { (b) } & 24 & 14: 10 & 68\end{array}$

270

$\begin{array}{lllll}\text { (a) }^{5} & 30 & 18: 12 & 84 & 330\end{array}$

(b) $30 \quad 14: 16 \quad 92$

GST $\alpha$

118
Hph $1^{\wedge} \quad 69+49$

N.K.

$\begin{array}{lll}\text { Bvu 1 } & 129+74 & \text { N.K. } \\ \text { Ban II } & 129+74 & \\ \text { Apa 1 } & 129+74 & \\ \text { EcoN 1 } & 115+65 & \begin{array}{l}2,280 \text { bp } \\ \text { (D'Arpa et al., 1988; } \\ \text { Kunze et al., 1991) }\end{array}\end{array}$

Hind III $129+87 \quad$ N.K.

Alu $1^{\wedge} \quad 87+52 \quad$ N.K.

$\begin{array}{lll}\text { Sty } 1 & 171+99 & \mathbf{7} 49\end{array}$

(EMBL no. X08058)

$\begin{array}{lll}\text { Hind III } & 206+124 & 4,630 \\ \text { Hsu 1 } & 206+124 & \text { (Klöne et al., 1992; } \\ \text { Msp 1 } & 228+102 & \text { Tu and Qian, 1986; } \\ & & \text { EMBL no.s X65726, } \\ & & \text { X65734) }\end{array}$

Hinc II $\quad 246+81 \quad 755$

(Jaiswal et al., 1985a)

$\begin{array}{lllll}\text { (a) } & 21 & 12: 9 & 60 & 327\end{array}$

(b) $21 \quad 14: 7 \quad 56$

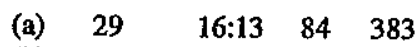

(b) 22

$12: 10 \quad 64$
383
3. Micro- (a) 20

globulin* (b) 20 $\begin{array}{lll}11: 9 & 58 & 114 \\ 12: 8 & 56 & \end{array}$

(Chen et al., $1986 ; 1990$ )

$2580-2603$
$2877-2900$
(van der Bliek et al.,
1988)

$1317-1337$

$1499-1519$

(EMBL no. LOS628)

$1123-1152$

$1276-1302$

(D'Arpa et al., 1988)

$1395-1412$

$1585-1610$

(Tsai-Pflugfelder et al., 1988)

$4052-4072$

$4165-4190$

(Tsai-Pflugfelder et al., 1988)

$4335-4364$

$4425-4452$

(Jenkins et al., 1992)

(EMBL no. X68060)

$58-75$

$304-327$

(Moscow et al., 1989)

$235-264$

$535-564$

(Tu and Qian, 1986)

$1021-1041$

$1327-1347$

(Jaiswal et al., 1985b)

Hin f $1 \quad 193+190 \quad 590 \quad 619-647$

Hph $1 \quad 266+117 \quad$ (EMBL no. M10277) $\quad 980-1001$

(EMBL no. X0035I, M10277)

$271-290$

$365-384$ 
Topo II

When choosing primers for Topo II in general, the $\mathrm{C}$-terminus and the extreme $\mathrm{N}$-terminal regions were avoided as these are the main areas where $\Pi \alpha$ and II $\beta$ diverge in structure. The chosen primers are both $100 \%$ homologous to the Topo II mRNA template, resulting in a region of $216 \mathrm{bp}$ being amplified. Digesting with Hind III restriction enzyme produces bands of $129 \mathrm{bp}$ and $87 \mathrm{bp}$. The primers are not equal in length. However, this seemed unavoidable when attempting to maximise their specificity. Many sequences were chosen as potential primers, but the primer pair 1395-1412 and 1585-1610 (Tsai-Pflugfelder et al., 1988) were favoured by comparison to the others as they are independently homologous to fewer other human sequences and they do not share common homologies other than Topo II. The annealing temperature for Topo $I$ (a) primer is slightly below the recommended range; the Topo $\Pi(b)$ primer is within this range. Neither primer contains palindromes or stretches of polypurines or polypyrimidines. Due to the unavailability of the Topo II genomic sequence, it is uncertain whether or not these primers span or cross introns.

\section{Topo $I I \alpha(I I \alpha)$}

The longest region of divergence between $I \alpha$ and II $\beta$ was considered to be the best area to choose specific primers for $\Pi \alpha$ and $\Pi \beta$ respectively. This is the C-terminal region (Jenkins et al., 1992). As the region of divergence between $\mathrm{II} \alpha$ and II $\beta$ is relatively small, primers that span the longest region possible were favoured. This is so that the product and the restriction enzyme digestion prod- uct can be easily detected on a gel. A number of potential $3^{\prime}$ primers were not chosen for $\amalg \alpha$ as they contained stretches of polypurines and polypyrimidines. To avoid these and other problem areas, primers 4052-4072 and 4165-4190 (TsaiPflugfelder et al., 1988) were chosen. Although the $139 \mathrm{bp}$ region amplified is homologous with that of II $\beta$ to a small extent (Jenkins et al., 1992) the primers are specific for II $\alpha$. Digestion with Alu 1 restriction enzyme results in stretches of $87 \mathrm{bp}$ and 52 bp being produced. The annealing temperature for the $5^{\prime}$ primer is within the recommended range, but that for the $3^{\prime}$ primer is slightly high. Both primers are independently homologous to a number of other human sequences, but do not seem to share common homologies.

\section{$I I \beta(I I \beta)$}

The II $\beta$ primers (4335-4364 and 4425-4452, Jenkins et al., 1992; EMBL accession no. X68060) amplify a 118 bp region unique to IrB. Digestion with Hph 1 restriction enzyme results in $69 \mathrm{bp}$ and 49 bp products. The primers are quite long $-30 \mathrm{bp}$ and $28 \mathrm{bp}$, respectively, to increase their specificity. They have an annealing temperature slightly above the recommended range. Neither primer contains palindromes or lengths of polypurines or polypyrimidines. Both these primers, too, are independently homologous to a number of human sequences, but they apparently do not share common human homologies (with the exception of II $\beta$ ).

\section{$\beta$-Actin}

As discussed in "Quantitative PCR", it is very difficult to find primers that are specific for $\beta$-actin

Notes to Table 1:

* This primer was not selected' in-our laboratory, but was published by Noonan et al. (1990).

When numbering all primers " $A$ " of the start codon was considered as position " 1 ".

$\beta_{2}$-microglobulin may be used as an internal control when amplifying this sequence if diagnostic digestion with a restriction enzyme s to be included. This is because the region amplified with the primers chosen for $\beta$-actin has also a site present for this restriction inzyme, whereas the $\beta_{2}$-microglobulin region does not.

GST- $\alpha$ primers were chosen on the human liver cDNA templates (clone pGTH1 and pGTH2) and the human kidney cDNA template GST $\alpha 12 \mathrm{k}$ ), according to the sequences published by Klöne and co-workers (1992). GST $\alpha$ (a) primer is located on exon 4 and primer b) spans from exon 6 to exon 7 (Klöne et al, 1992).

V.K. = Not known. 
and do not recognise other actin forms. The $\beta$-actin primer pair published here are also homologous to mutant $\beta$-actin (EMBL accession no. X63432). This was unavoidable when the other actin forms were avoided and the guidelines for choosing primers were considered, as the normal (EMBL accession no. X00351) and the mutant forms differ only by one nucleotide in the amplified region.

\section{Glutathione-S-transferase $\pi$ (GST $\pi$ )}

The cDNA sequence of GST $\pi$ (Moscow et al., 1989) apparently differs from that of human myocardial fatty acid ethyl esters-II (FAEE-III) (Bora et $a l ., 1991)$ by only six nucleotides. As primers specific for GST $\pi$ could not be found, an effort was made to find a restriction enzyme recognition site that is present in the GST $\pi$ amplified region but not in FAEE-III, or vice versa (due to the four nucleotide sequence difference in this region). However, such a site was not identified. According to Bora and co-workers (1991) the sequence differences between GST $\pi$ and FAEE-III are not due to sequence errors, but reflect inherent functional differences. This should be considered when studying certain tissue types as expression of FAEE-III mRNA has been reported in normal human liver, placenta and heart (Bora et al., 1991).

From the above examples, it is obvious that choosing specific primers representing all the suggested guidelines is not possible in all situations.

\section{Appendix 1}

\section{Preparation for RNA extraction}

RNases are ubiquitous in the environment and so precautions must be taken to avoid their introduction while extracting RNA.

- General laboratory glassware and plasticware are often contaminated by RNases: Glassware should be treated by baking at $180^{\circ} \mathrm{C}$ for $8 \mathrm{~h}$, or more. Plasticware should be rinsed with chloroform. All spatulas which may come in contact with any of the solution components should be baked (as for glassware), the chemicals weighed out onto baked tin-foil and a stock of chemicals kept separate, for "RNA extraction only", from general stocks.

- Sterile, disposable plasticware is essentially free of RNases and can be used for the preparation and storage of RNA without pretreatment. However, polyallomer ultracentrifuge tubes, eppendorf tubes, pipette tips, etc. for the RT reaction (and any other glassware not baked) can be filled with DEPC $\left(0.1 \%(v / v)\right.$ in water) and stored at $37^{\circ} \mathrm{C}$ for $2 \mathrm{~h}$ (or more), rinsed several times with sterile ultra-pure water and then autoclaved (Sambrook et al., 1989). We have not found it necessary to DEPC-treat eppendorfs and tips in our laboratory.

- Solutions that come in contact with the RNA, after lysing the cells in guanidinium solution, should all be prepared in baked glassware, made from sterile ultra-pure water and treated with $0.1 \%$ DEPC before autoclaving, with the exception of Tris containing solutions (DEPC reacts with amines and so is inactivated by Tris).

- Gloves should be worn at all times to protect both the operator and the experiment. This, again, prevents the introduction of RNases and foreign RNA/DNA into the RT and PCR reactions. Gloves should be changed frequently.

\section{Protocol 1: total RNA isolation}

The following procedure is conducted in a laminar flow to maintain sterile conditions and prevent the introduction of contaminants.

\section{Cultured cells}

Cells are grown in $135 \mathrm{~mm}$ diameter petri-dishes, until approximately $80 \%$ confluent. The medium is removed. The following procedure is then followed:

1. Rinse twice in phosphate-buffered saline (PBS).

2. Lyse in guanidinium thiocyanate ( $\mathrm{GnSCn}$ ) solution; (It is generally recommended that the cell lysate be homogenised for 1-2 mins. This serves to shear the nuclear DNA and so prevent the formation of an impenetrable layer at the top of the cushion of $\mathrm{CsCl}$ which might block sedimentation of the RNA to the bottom of the centrifuge tube).

3. Layer onto $5.7 \mathrm{M}$ cesium chloride ( $\mathrm{CsCl}$ ) cushion in ultracentrifuge tube.

4. Centrifuge at $26,000 \mathrm{rpm}$ at $15^{\circ} \mathrm{C}$ for $21-24 \mathrm{~h}$; (Centrifuging in a swinging-bucket rotor causes the RNA to be deposited at the bottom of the centrifuge tube and so prevents it coming in contact with the cell lysate).

5. Remove GnSCn and the "jelly-like" layer just below the $\mathrm{GnSCn} / \mathrm{CsCl}$ interface by aspiration; change pasteur pipette and remove all but approximately $1 \mathrm{ml}$ of the $\mathrm{CsCl}$ layer (to prevent disruption of the RNA pellet).

6. Quickly invert the tubes to drain.

7. Cut off the bottom of the tube containing the RNA pellet using a heated scalpel blade.

"DEPC (diethyl procarbonate) is a strong, but not absolute, inhibitor of RNases: Warning: DEPC is suspected to be carcinogenic - due care should be exercised. 
8. Rinse the pellet with $95 \%$ ethanol at room temperature.

9. Resuspend the RNA pellet in $200 \mu l$ of DEPC-treated water by gently pipetting it up-and-down, whilst keeping tube on ice.

10. Rinse suspension remains into an eppendorf tube using a further $200 \mu \mathrm{l}$ of DEPC-treated water.

1. Precipitate RNA out of solution by the addition of $3 \mathrm{M}$ sodium acetate (to result in a final concentration of $0.3 \mathrm{M}$ ) and two volumes of ice-cold absolute ethanol (overnight at $-20^{\circ} \mathrm{C}$ or $30 \mathrm{~min}$ at $-80^{\circ} \mathrm{C}$ ).

2. Pellet RNA by centrifuging at $4^{\circ} \mathrm{C}$; remove supernatant and dry pellet briefly. (Ensure that the pellet does not dry completely as this greatly decreases its solubility. The solubility of RNA can be improved by heating to $55-60^{\circ} \mathrm{C}$ with intermittent vortexing or by passing the RNA solution through a pipette tip, if necessary).

3. Resuspend pellet in $50 \mu \mathrm{l}$ DEPC-treated water. (Susan Mc Donnell, pers. comm).

\section{Vhole tissue}

the case of whole tissue, the tissue is stored in liquid itrogen immediately upon its removal from the body, until eady to be analysed. At this stage it is pulverised very finely sing a mortar and pestle and homogenised in denaturing InSCn) solution, without thawing. The above procedure (for altured cells) is then followed from (3).

\section{NA quantitation}

NA is quantified spectrophotometrically at $260 \mathrm{~nm}$ and 280 $n$. The $A_{260} / A_{280}$ ratio of RNA is approximately 2. Partially lubilised RNA has a ratio < 1.6 (Ausubel et al., 1991a).

. The yield of RNA from most lines of cultured cells is 0-200 $\mathrm{gg}$ per $90 \mathrm{~mm}$ plate (Sambrook et al., 1989).

(For further information see: Sambrook et al., (1989) Ch. "Extraction, Purification and Analysis of Messenger RNA m Eukaryotic Cells" In: Molecular Cloning: A Laboratory anual. (second addition) pp. $7.2-7.83$ and Ausubel et al. 991a) Ch. 4. "Preparation and Analysis of RNA". In: Current otocols in Molecular Biology, Vol. 1 pp. 4.0.1-4.10.9).

\section{otocol 2: typical RT reaction}

mponent:

Volume:

go (dT) 12-18 primers $(1 \mu \mathrm{g} / \mu \mathrm{l})$

$1.0 \mu \mathrm{l}$

$1.0 \mu \mathrm{l}$

$3.0 \mu 1$

C for $10 \mathrm{~min}$; chill on ice.

is should get rid of any RNA secondary structure formation allow the oligo (dT) primers to bind to the poly (A) region the mRNA).
Then add:

Volume:

$5 X$ Buffer

DTT (100 mM)

$4.0 \mu \mathrm{l}$

RNasin (40 U/ $\mu \mathrm{l})$

dNTPs (10 $\mathrm{mM}$ each)

$\mathrm{H}_{2} \mathrm{O}$

MMLV-RT (200 U/hl)

$2.0 \mu 1$

$1.0 \mu \mathrm{l}$

$1.0 \mu \mathrm{l}$

$6.0 \mu \mathrm{l}$

$1.0 \mu \mathrm{l}$

$37^{\circ} \mathrm{C}$ for $1 \mathrm{~h}$, followed by $95^{\circ} \mathrm{C}$ for 2 min (Susan Mc Donnell, pers. comm).

\section{SX Buffer}

$250 \mathrm{mM}$ Tris-HCl, pH 8.3; $375 \mathrm{mM} \mathrm{KCl} ; 15 \mathrm{mM} \mathrm{MgCl}$.

The successful use of the PCR buffer instead of this $5 \mathrm{X}$ buffer in the reverse transcriptase reaction has been reported by Kawasaki (1989). Better results were achieved using the PCR buffer, at least when reverse transcribing short RNA sequences. This, it is suggested, simplifies the protocol by eliminating the possibility of differences in optimal monovalent and divalent ionic strengths between the two buffers,

RNasin

An inhibitor of ribonuclease enzymes is included in the RT reaction. This is to prevent degradation of RNA by ribonucleases. RNasin is a broad spectrum ribonuclease inhibitor which acts by binding noncovalently to ribonucleases enzymes. RNasin is unstable at temperatures of $50^{\circ} \mathrm{C}$ or above. As ribonucleases are capable of retaining their degradative properties under denaturing conditions, such temperatures should be avoided for the RT reaction to prevent release of active ribonuclease enzymes.

\section{Dithiothreitol (DTT)}

The concentration of DTT is critical as RNasin requires $1 \mathrm{mM}$ DTT to prevent its dissociation from the RNases (Susan Mc Donnell, pers. comm).

\section{Deoxynucleotide triphosphates (dNTPs)}

The dNTPs (dATP, dCTP, dGTP and dTTP) are aliquoted as a mix at a concentration of $10 \mathrm{mM}$ each. These are the precursors of the cDNA strand.

Moloney murine leukemia virüs reverse transcriptase (MMLVRT)

MMLV-RT is the reverse transcriptase enzyme used to form cDNA on the primed mRNA template. (MMLV H RT, a recombinant enzyme has been engineered to have no RNase $H$ activity. This is claimed to result in greater yields of cDNA including full-length sequences).

RT-PCR can be simplified by the fact that Taq DNA polymerase also exhibits reverse transcriptase activity at $68^{\circ} \mathrm{C}$ 
(Jones and Foulkes, 1989). RT-PCR using one enzyme was conducted by Shaffer et al. (1990) in a study of interleukin-2 mRNA in gibbon $T$ cells.

The use of Taq DNA polymerase as the enzyme catalysing the RT reaction may have some advantages over MMLV-RT. The RT reaction in the presence of reverse transcriptase enzyme generally takes approximately an hour. Using Taq DNA polymerase, cDNA can be formed in a number of minutes (Shaffer et al., 1990; Singer-Sam et al., 1990). Taq DNA polymerase enzyme is much more heat-stable than MMLV-RT, which allows the reaction to be conducted at higher temperatures. This should increase the primer stringency and help eliminate RNA secondary structure. However, optimum reverse transcription using Taq DNA polymerase may require the addition of magnesium (Bej et al., 1991).

\section{Trouble-shooting}

Rappolee (1990) reported first-strand cDNA synthesis by reverse transcription to be a technique of variable efficiency between preparations and between RNA species. To overcome secondary structure problems in RNA, a number of recommendations are made. These include: increasing the RT reaction temperature from 37 to $55^{\circ} \mathrm{C}$ ( $T a q$ DNA polymerase seems to be more staple at high temperatures than reverse transcriptase enzymes); increasing the reverse transcription enzyme concentration from $1 \mathrm{X}$ to $3 \mathrm{X}$ or more and using random hexanucleotide primers and/or $3^{\prime}$ antisense oligonucleotide priming. To improve sensitivity, the first strand synthesis may be repeated after heat denaturation. Reverse transcriptases have some amount of heat stability, but it is often advisable to add a fresh aliquot of enzyme for greater efficiency if a second cycle of reverse transcriptase is included. (This further addition of enzyme may not be necessary if Taq DNA polymerase reverse transcriptase activity is taken advantage of).

\section{Polymerase chain reaction}

Once the cDNA copy has been created using the mRNA template, a typical PCR reaction is conducted as below. Concentrations, temperatures, volumes and times may need to be varied to optimise reaction conditions to suit the need of a particular template and primer pair. (For further details see: Innis and Gelfand, 1990; Taylor, 1991).

\section{Protocol 3: PCR reaction}

Component:

$$
\mathrm{H}_{2} \mathrm{O}
$$

10X Buffer $\left(\mathrm{MgCl}_{2}\right.$ free $)$

$\mathrm{MgCl}_{2}(25 \mathrm{mM})$

dNTP $(1.25 \mathrm{mM})$

Target primer (1) $(250 \mathrm{ng} / \mu \mathrm{l})$

Target primer (2) (250 $\mathrm{ng} / \mu \mathrm{I})$

Internal control primer (t) $(250 \mathrm{ng} / \mu \mathrm{l})$
Internal control primer (2) $(250 \mathrm{ng} / \mu \mathrm{l})$

Taq DNA polymerase (5 U//l)

$1 \mu$ l

$0.5 \mu \mathrm{I}$

Template:

cDNA (from RT reaction)

Volume:

$5 \mu \mathrm{l}$

before adding to the PCR reaction components.

Add a drop of mineral oil;

Amplify using the following procedure:

$-95^{\circ} \mathrm{C}$ for 1.5 min (denature ds DNA).

- 30 cycles: $95^{\circ} \mathrm{C}$ for $1.5 \mathrm{~min}$ (denature); $55^{\circ} \mathrm{C}$ for $1 \mathrm{~min}$ (anneal);

$72^{\circ} \mathrm{C}$ for 3 min (extend)

$-72^{\circ} \mathrm{C}$ for $7 \mathrm{~min}$ (extend).

- Hold at $4^{\circ} \mathrm{C}$.

(Susan Mc Donnell, pers. comm).

The result of the RT-PCR can be analysed by agarose gel electrophoresis. Ethidium bromide intercalates with the cDNA forming a product that is readily visible under ultraviolet transillumination.

\section{IOX buffer}

$100 \mathrm{mM}$ Tris- $\mathrm{HCl}\left(\mathrm{pH} 9.0\right.$ at $25^{\circ} \mathrm{C}$ ); $50 \mathrm{mM} \mathrm{KCl} ; 1 \%$ Triton X100.

The 10X buffer is generally supplied with the Taq DNA polymerase enzyme.

$\mathrm{MgCl}_{2}:(25 \mathrm{mM})$

Magnesium chloride is usually supplied with the Taq DNA polymerase enzyme, but as a separate entity to the $10 \mathrm{X}$ buffer. The magnesium chloride concentration in the buffer has been found to greatly influence the PCR result. It is generally advised to vary the concentration of magnesium chloride (usual range $1-8 \mathrm{mM}$ ) to determine the optimum concentration of this component.

\section{Deoxynucleotide triphosphates (dNTPs)}

The dNTPs for the PCR are aliquoted as a mix (dATP, dCTP, dGTP and dTTP) at a final concentration of $1.25 \mathrm{mM}$ each. These are the required precursors for the synthesis of new cDNA strands.

Primers (see "criteria to follow when choosing primers")

A primer pair is included in the PCR which is specific for the target cDNA region of interest. It is also advisable to include a primer pair which will result in amplification of an ubiguitously occurring cellular component. This will serve as an internal control (see "Quantitative PCR"). 
Taq DNA polymerase enzyme

(Previously discussed).

Mineral oil

The purpose of the mineral oil is to prevent evaporation of the reaction components when subjected to the high temperatures required for melting the double-stranded DNA to single-strands.

\section{Solutions for total RNA extraction}

$4 M$ guanidinium thiocyanate:

Guanidinium thiocyanate salt (Sigma G-6639) $50 \mathrm{~g}$

N lauroyl sarcosine (Sigma L-5125)

$1 \mathrm{M}$ Na citrate, $\mathrm{pH} 7$

$0.5 \mathrm{~g}$

$5 \mathrm{ml}$

Bring to $100 \mathrm{ml}$ with $\mathrm{H}_{2} \mathrm{O}$; stir until dissolved (can heat gently); check $\mathrm{pH}$ is approximately 7 ; filter through $0.45 \mu$ filter; store at room temperature in dark bottle.

Before use add:

B-mercaptoethanol (Sigma M6250)

Antifoam A (30\%) (Sigma A-5758)

$700 \mu 1 / 100 \mathrm{ml}$ $330 \mu \mathrm{l} / 100 \mathrm{ml}$

\section{$5.7 \mathrm{M} \mathrm{CsCl}$}

CsCl (C-3032)

$1 \mathrm{M}$ Na citrate, pH 7

$95.8 \mathrm{~g}$

$2.5 \mathrm{ml}$

Bring to $100 \mathrm{ml}$ with $\mathrm{H}_{2} \mathrm{O}$; filter sterilize; DEPC-treat and autoclave; store at room temperature.

IM. sodium citrate

Na citrate (RDH 32320)

$29.4 \mathrm{~g}$

Bring to $80 \mathrm{ml}$ with $\mathrm{H}_{2} \mathrm{O}$; $\mathrm{pH}$ to 7 with $\mathrm{HCL}$; bring to $100 \mathrm{mls}$; filter sterilise; store at room temperature.

Note: $\mathrm{H}_{2} \mathrm{O}$ used in all solutions should be sterile ultra-pure $\mathrm{H}_{2} \mathrm{O}$. (Susan McDonnell, pers, comm.)

\section{Appendix 2}

Using cDNA sequence data-bases to check uniqueness of primers

The most critical element in choice of primers for PCR is obviously that the primers are unique i.e., that they do not cross-react with sequences likely to be present in the mRNA of the cells/tissues being studied. This involves choice of primers using the criteria described above, and checking via a DNA data-base (e.g., EMBL, GenBank) what similar sequences exist. This approach is essential if no references are available on RTPCR of the mRNA in question. Even where references do exist, there is need for checking because:

- the cDNA data-base is expanding rapidly and new crossreactions may have been discovered since the choice of primers was published;

- occasionally, published primers have not been well chosen and cross-reactions have been overlooked; also, occasionally, probably due to typographicăl errors, incorrect primer sequences are published.

Because of the excellent search facilities available, checking sequence uniqueness of primer sequences is a straightforward procedure. Such searching is routine in many laboratories, but for readers without experience in this area we wish to emphasize here how simple the procedures are, and that no great expertise in either molecular biology or computing is required.

For example, EMBL DNA data bases can be accessed easily via E-Mail by linking to large mainframe computers (e.g., VAX) which are accessible to most universities or hospital laboratories. In our laboratory, we have installed software (KERMIT) to allow our IBM-PCs to be used as VAX terminals for E-Mail. Once E-Mail has been accessed on the PC (through use of KERMIT commands and the appropriate user number and password given to us by the Central Computer Office in the University) we can send a primer sequence to be checked (e.g., to $\mathrm{EMBL}$ ) by the following procedure:

\section{Note:}

Italics = prompts received;

Bold = to be typed in;

[R] = "return" key;

CTRL/Z = press "control" key and "Z", simultaneously.

Username: $\mathbf{x x x x x \times x x}[\mathrm{R}]$

Password: yyyyyyyy [R]

$\$ \quad$ mail

Mails send

To: In\%"Fasta@embl-heidelberg.de" [R]

Subj: (not necessary to choose subject) [R]

Enter your message below. Press CTRLZ when complete or $C T R L / C$ to quit:

Lib email [R] (can choose to check a particular library in this way)

Align 20 [R] (can choose how many alignments required. Default is 30)

Seq [R]

CCCATCATTGCAATAGCAGG[R] (The example given here is the $M D R I$ primer (a) sequence - see Table 1).

end $[R]$

CTRL/Z [R]

If you have an accession number e.g., for a cDNA sequence, and wish to obtain the cDNA sequence, the address and procedure is slightly different:

Mail> send [R]

To: In\%"Netserv@embl-heidelberg.de" [R]

Subj: [R] 
Enter your message below. Press CTRL/Z when complete or CTRL/C to quit:

GET NUC:X00351 [R] (The example shown here is the EMBL. accession number of human mRNA for $\beta$-actin). CTRL/Z

To access returned mail:

Mail> dir [R] (will give a list of your directory of returned messages)

Mail $>\mathbf{3}[\mathbf{R}]$ (choose the number of any of the listed return messages e.g., no. 3)

By pressing [R] you can read through the message or

Mail> print $[\mathrm{R}]$

CTRL/Z (if want message printed).

After use, when have exited by using CTRL/Z command

$\$$ lo (to exit system).

Depending on the pressure on the EMBL facility at the time, a list of related sequences will be sent back to us in minutes or hours. (Note: The location and hence E-Mail address for EMBL is scheduled to change in mid-1995).

A more detailed account of facilities available and relevant software is beyond the scope of this review. The reader is referred to recent summaries of services provided via EMBL (Rice et al., 1993) and Genbank (Benson et al., 1993) to an introductory book on the subject (Bishop and Rawlings, 1987) and to supplement 19, "Current Protocols in Molecular Biology" (1992) Unit 7.7 which provides a good introduction to databases and to some software useful for sequence analysis and comparison.

\section{References}

Alwine JC, Kemp DJ and Stark GR (1977) Method for detection of specific RNAs in agarose gels by transfer to diazobenzyloxymethyl-paper and hybridisation with DNA probes. Proc. Nat Acad. Sci. USA 74(12): 5350-5354.

Ausubel MA, Brent R, Kinston RE, Moore DD, Seidman JG, Smith JA and Struhl K (eds) (1991a) Current protocols in molecular biology (pp. 4.0.1-4.1.0.9). Greene Publishing Associates and Wiley Interscience, New York.

Ausubel MA, Brent R, Kinston RE, Moore DD, Seidman JG, Smith JA and Struhl K (eds) (1991b) Current protocols in molecular biology (pp. 14.0.1-14.6.13). Greene Publishing Associates and Wiley Interscience, New York.

Ausubel MA, Brent R, Kinston RE, Moore DD, Seidman JG, Smith JA and Struhl K (eds) (1991c) Current protocols in molecular biology (pp. 15.0.1-15.5.16). Greene Publishing Associates and Wiley Interscience, New York.

Avraham H, Vannier E, Chi SY, Dinarello CA and Groopman JE (1992) Cytokine gene expression and synthesis by human megakaryocytic cells. Int. J. Cell Cloning 10: 70-79.

Becker-Andre $M$ and Hahlbrock K (1989) Absolute mRNA quantification using the polymerase chain reaction (PCR). A novel approach by a PCR aided transcript titration assay (PATTY). Nuc. Acids Rès. 1722: 9437-9446.

Bej AK, Mahbubani MH and Atlas RM (1991) Amplification of nucleic acids by polymerase chain reaction (PCR) and other methods and their applications. Crit. Rev. Biochem. Mol. Biol. 26(3/4): 301-334.

Benson D, Lipman DJ and Ostell J (1993) GenBank. Nuc. Acids Res. 21: 2963-2965.

Bishop MJ and Rawlings CJ (eds) (1987) Nucleic acids and protein sequence analysis: a practical approach. IRL Press, Oxford.

Bloch W (1991) A biochemical perspective of the PCR reaction. Biochemistry 30(11): 2735-2747.

Bora PS, Bora NS, Wu X and Lange LG (1991) Molecular cloning, sequencing, and expression of human myocardial fatty acid ethyl ester synthase-III cDNA. J. Biol. Chem. 266: 16774-16777.

Bourhis J, Goldstein LJ, Riou G, Pastan I, Gottesman MM and Benard J (1989) Expression of a human multidrug resistance gene in ovarian carcinomas. Cancer Res. 49: 5062-5065.

Brenner CA, Tam AW, Nelson PA, Engleman EG, Suzuki N, Fry KE and Larrick JW (1989) Message amplification phenotyping (MAPPing) a technique to simultaneously measure multiple mRNAs from small numbers of cells. Biotechniques 7: 1096-1103.

Byme BC, Li JJ, Shinsky J and Poiesz BJ (1988) Detection of HIV-1 RNA sequences by in vitro DNA amplification. Nuc. Acids Res. 16(9): 4165.

Chelly J, Kaplan J-C, Maire P, Gautron S and Kahn A (1988) Transcription of the dystrophin gene in human muscle and nonmuscle tissue. Nature 333: 858-860.

Chen C-J, Chin JE, Ueda K, Clark DP, Pastan I, Gottesman MM and Roninson IB (1986) Internal duplication and homology with bacterial transport proteins in the $m d r l$ ( $\mathrm{p}$ glycoprotein) gene from multidrug-resistant human cells. Cell 47: 381-389.

Chen C-J, Clark D, Ueda K, Pastan I, Gottesman MM and Roninson IB (1990) Genomic organization of the human multidrug resistance (MDRI) gene and origin of P-glycoproteins. J. Biol. Chem. 265: 506-514.

Chin JE, Soffir R, Noonan KE, Choi K and Roninson I (1989) Structure and expression of the human MDR (P-glycoprotein) gene family. Mol. Cell Biol. 9(9): 3808--3820.

Chirgwin JJ, Przybyla-AE, MacDonald RJ and Rutter WJ (1979) Isolation of biologically active ribonucleic acid from sources enriched in ribonuclease. Biochemistry 18: 52945299.

Choi K, Chen C-J, Kriegler M and Roninson IB (1988) An altered pattern of cross resistance in multidrug resistant human cells results from spontaneous mutations in the mdr1 (P-glycoprotein) gene. Cell 53: 519-529.

Clarkson T, Güssow D and Jones PT (1991) General application of PCR to gene cloning and manipulation. In: MCPherson MJ, Quirke P and Taylor GR (eds) PCR. A Practical 